\title{
Seismic vulnerability assessment of multi-storey subway station structure
}

\author{
Tong Liu ${ }^{1, *}$, Zhixin $\mathrm{Li}^{2}$, Qinghe Wang ${ }^{3}$, Huaiyu $\mathrm{Xu}^{3}$ \\ ${ }^{1}$ School of Management, Shenyang Jianzhu University, Shenyang 110168, China. \\ ${ }^{2}$ Shenyang Urban Construction Tianhe Real Estate Company Limited, Shenyang 110168, China. \\ ${ }^{3}$ School of Civil Engineering, Shenyang Jianzhu University, Shenyang 110168, China.
}

\begin{abstract}
The safety of underground structure under seismic load is an important basis of the normal operation of underground rail transit system. Structural seismic vulnerability assessment based on incremental dynamic analysis method can evaluate the probability of the structure exceeding a certain limit state under a specific seismic intensity in terms of probability. In this paper, the seismic vulnerability of a multi-storey subway station structure is evaluated using this method, and a two-dimensional finite element model of both soil and structure is established by finite element software ABAQUS. The vulnerability curve is obtained through incremental dynamic analysis and mathematical statistics. Based on this curve, the probabilities of the structure exceeding four seismic limit states are obtained under the design seismic intensity and the rarely occurred seismic intensity at 7 degree. Results show that this station may attain slight damage under design seismic intensity of 7 degree, and may attain life safety at the rarely occurred seismic intensity at 7 degree.
\end{abstract}

\section{Introduction}

In earlier years, the researchers generally agree that the seismic performance of underground structure is better than that of the surface structure. However, the Daikai subway station encountered $M$ type failure mode during the Kobe earthquake at Japan in $1995^{[1,2]}$. Therefore, seismic performance of underground structure should obtain enough attention. With the continuous development of science and technology, underground space is fully exploited and the layer of underground subway station structure increases. Consequently, it is necessary to do research on the seismic performance of multi-storey underground subway station.
Among the approaches of evaluating seismic performance, seismic vulnerability assessment based on incremental dynamic analysis(IDA) can evaluate the probability of the structure exceeding a certain limit state under a specific seismic intensity in terms of probability ${ }^{[3,4]}$. At the same time, the method can fully take the randomness of seismic ground motion and structural dynamic response characteristics under strong earthquake into consideration. This method has been applied to the seismic vulnerability assessment of conventional underground structures ${ }^{[5,6]}$.

Considered the advantages of seismic vulnerability assessment, in this study, the seismic vulnerability of multi-storey subway station is carried out. A twodimensional numerical model of a four-storey three-span structure and the surrounding soil is developed

Table1. Soil parameters of the example structure.

\begin{tabular}{|c|c|c|c|c|c|c|c|}
\hline Sequence & Name & Depth $(\mathrm{m})$ & $\begin{array}{c}\text { Unit } \\
\text { Weight } \\
\left(\mathrm{kN} / \mathrm{m}^{3}\right)\end{array}$ & $\begin{array}{c}\text { Elastic } \\
\text { Modulus } \\
(\mathrm{MPa})\end{array}$ & $\begin{array}{c}\text { Poisson's } \\
\text { Ratio }\end{array}$ & $\begin{array}{c}\text { Friction } \\
\text { Angle } \\
\left({ }^{\circ}\right)\end{array}$ & $\begin{array}{c}\text { Cohesion } \\
(\mathrm{kPa})\end{array}$ \\
\hline 1 & Man-made fill & $0 \sim 0.5$ & 1820 & 14 & 0.32 & 14.5 & 21 \\
\hline 2 & Man-made fill & $0.5 \sim 1.3$ & 820 & 14 & 0.32 & 14.5 & 21 \\
\hline 3 & $\begin{array}{c}\text { Brownish yellow to } \\
\text { grayish yellow silty clay }\end{array}$ & $1.3 \sim 3.2$ & 820 & 14 & 0.32 & 14.5 & 21 \\
\hline 4 & Grey silty silty clay & $3.2 \sim 8.4$ & 760 & 10 & 0.33 & 12.5 & 14 \\
\hline 5 & Grey silty clay & $8.35 \sim 14.8$ & 680 & 7 & 0.37 & 9.5 & 14 \\
\hline
\end{tabular}

\footnotetext{
* Corresponding author: 262liut@tongji.edu.cn
} 


\begin{tabular}{|c|c|c|c|c|c|c|c|}
\hline 6 & Gray clay & $14.8 \sim 18.2$ & 760 & 11 & 0.34 & 13.5 & 15 \\
\hline 7 & Gray silty clay & $18.2 \sim 22.4$ & 790 & 13 & 0.31 & 16.5 & 17 \\
\hline 8 & $\begin{array}{c}\text { Gray silty clay } \\
\text { interbedded with silt }\end{array}$ & $22.4 \sim 29.2$ & 800 & 17 & 0.29 & 18 & 16 \\
\hline 9 & Gray silty clay & $29.15 \sim 32.3$ & 840 & 16 & 0.31 & 16 & 24 \\
\hline 10 & Gray-green silty clay & $32.3 \sim 33.4$ & 980 & 26 & 0.26 & 19 & 34 \\
\hline 11 & $\begin{array}{c}\text { Grass yellow to cyan } \\
\text { sandy clay }\end{array}$ & $33.4 \sim 39.1$ & 900 & 33 & 0.26 & 29 & 5 \\
\hline 12 & Grass yellow to gray silt & $39.05 \sim 66.6$ & 870 & 43 & 0.24 & 31.5 & 3 \\
\hline 13 & Gray silty clay & $66.6 \sim 71.6$ & 820 & 17 & 0.23 & 14.5 & 26 \\
\hline 14 & Gray fine silty sand & $71.55 \sim 85$ & 890 & 45 & 0.25 & 34.5 & 0 \\
\hline
\end{tabular}

using the finite element software ABAQUS. Through incremental dynamic analysis, the vulnerability curves at four limit states are obtained, based on which the exceeding probabilities corresponding to four limit states at specific seismic intensity are ensured.

\section{Numerical modeling}

\subsection{Typical multi-storey subway station structure}

As shown in Figure 1, a four-storey three-span subway station is considered as a typical example of multi-storey subway station. The first underground floor is the stereo garage, the second underground floor is the lobby floor, the third underground floor is the device floor, and the bottom floor is the island platform floor. The section width of the station is $23.6 \mathrm{~m}$, and the height is $29.11 \mathrm{~m}$. The size of central column at the first and second underground floors is $0.7 \mathrm{~m}$ by $1.1 \mathrm{~m}$, while the size of central column at the third underground floor and the bottom floor is $0.7 \mathrm{~m}$ by $1.4 \mathrm{~m}$, and the longitudinal space of the central column along the station is $8 \mathrm{~m}$. The buried depth of the station is $2.9 \mathrm{~m}$ and the soil properties are shown in Table 1.

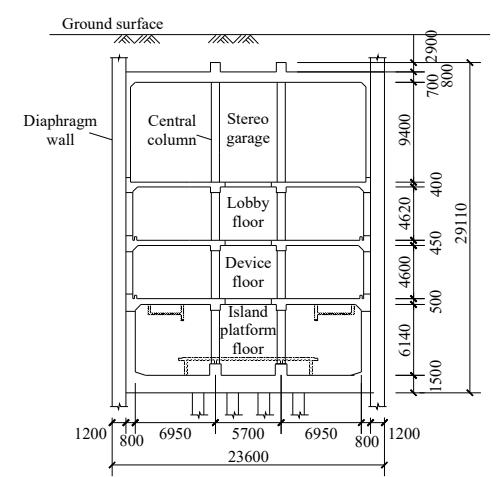

Figure 1. Cross section of the multi-storey subway station structure.

\subsection{Numerical model}

According to the general profile, a two-dimensional finite element model of soil and structure is established using finite element software ABAQUS ${ }^{[7]}$, the

Table2. Material Parameters of multi-storey subway station.

\begin{tabular}{|c|c|c|c|c|c|c|}
\hline \multirow{3}{*}{ Component } & \multicolumn{6}{|c|}{ Material } \\
\hline & \multicolumn{4}{|c|}{ Concrete } & \multicolumn{2}{|c|}{ Steel } \\
\hline & $\begin{array}{l}\text { Elastic } \\
\text { Modulus } \\
(\mathrm{GPa})\end{array}$ & $\begin{array}{l}\text { Axial Tensile } \\
\text { Strength (MPa) }\end{array}$ & $\begin{array}{c}\text { Axial Compression } \\
\text { Strength } \\
(\mathrm{MPa})\end{array}$ & $\begin{array}{c}\text { Possion's } \\
\text { Ratio }\end{array}$ & $\begin{array}{l}\text { Elastic Modulus } \\
\quad(\mathrm{GPa})\end{array}$ & $\begin{array}{l}\text { Yield strength } \\
(\mathrm{MPa})\end{array}$ \\
\hline $\begin{array}{l}\text { Central } \\
\text { column }\end{array}$ & 33.5 & 2.51 & 29.6 & 0.2 & 200 & 400 \\
\hline Others & 31.5 & 2.20 & 23.4 & 0.2 & 200 & 335 \\
\hline
\end{tabular}

dimension of which is $1000 \mathrm{~m}$ long and $85 \mathrm{~m}$ high, as shown in Figure 2. The structure members are simulated through beam element (B21) and the material properties of concrete and steel are illustrated in Table 2. The layered soil is simulated through 4-nodes plane strain element (CPE4R) and the quadrilateral plane strain infinite element (CINPE4). The interface between the soil and the structure is modeled as a frictional surface, among which coefficient of friction $\mu$ is equal to 0.4 and friction angle is $22^{\circ}$. Moreover, no cohesion exists between structure and soil and the ground motion is imposed at the bottom of the model. 


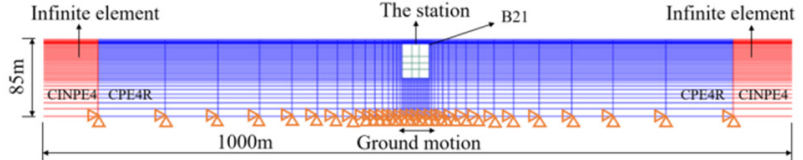

Figure 2. Finite element model

\section{Seismic vulnerability assessment process}

\subsection{Incremental dynamic analysis}

Based on the procedure of $\operatorname{IDA}^{[4]}$, the ground motion records are selected according to the site type, as shown in Table 3. Peak acceleration at the bottom of structure (PBA) is selected as intensity measure(IM) and the maximum inter-story drift angle $\left(\theta_{\max }\right)$ is chosen as the damage measure(DM). Besides, the ground motion records are scaled with Peak Velocity as 3, 5, 10, 20, 30,

$40,50,60,70,80 \mathrm{~cm} / \mathrm{s}$, and with nonlinear dynamic time-history analysis under each ground motion intensity, the IDA curves can be obtained, as shown in Figure 3. The range of $\theta_{\max }$ is 0 to $0.045 . \theta_{\max }$ increases gradually with the increasing of ground motion intensity and apparent discrepancy exists among each IDA curve. To better statistic IDA data, the IDA curves are arranged into $16 \%, 50 \%$ and $84 \%$ fractile curves to analyze the IDA calculation results in the mean sense, as illustrated in Figure 4 .

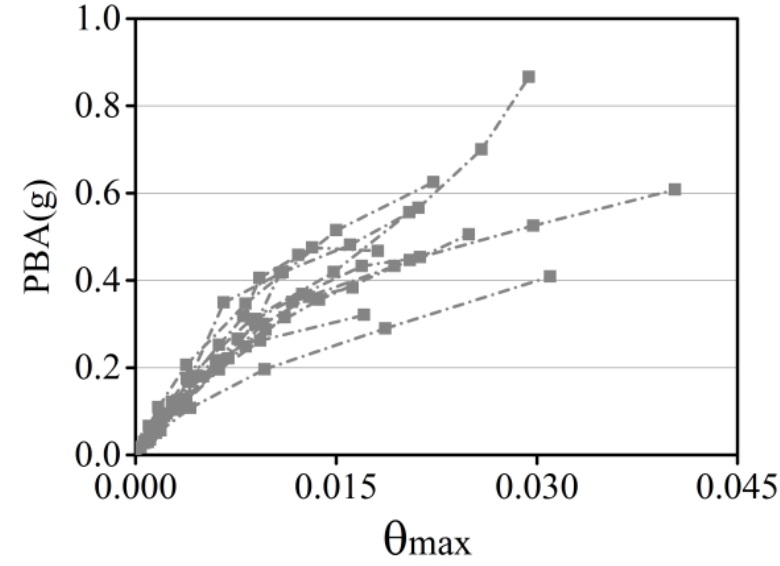

Figure 3. IDA curves

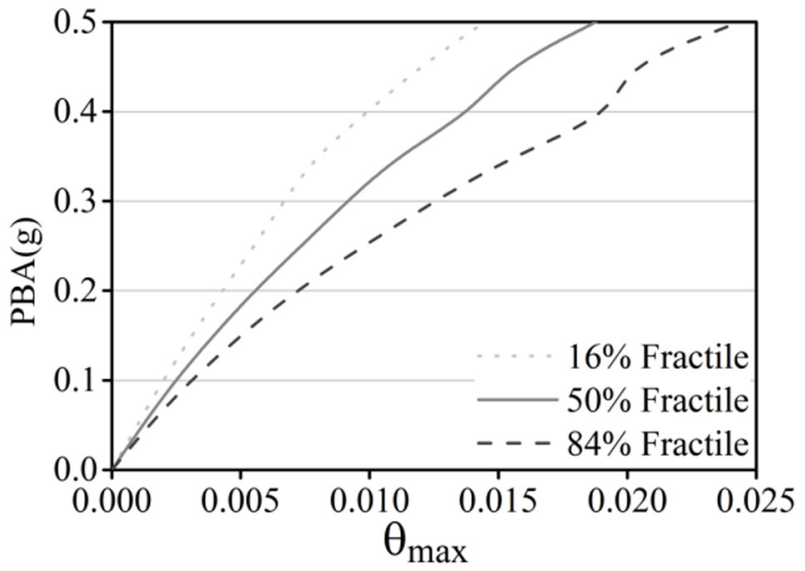

Figure 4. Fractile curves

Table3. Twelve ground motion records selected.

\begin{tabular}{|c|c|c|c|c|c|}
\hline No. & Event & Station & Component & PGA(g) & PGV(cm/s) \\
\hline M1 & $\begin{array}{c}\text { Imperial Valley-06, } \\
\text { 1979 }\end{array}$ & El Centro Array \#3 & E03140 & 0.267 & 47.97 \\
\hline M2 & $\begin{array}{c}\text { Imperial Valley-06, } \\
\text { 1979 }\end{array}$ & El Centro Array \#3 & E03230 & 0.223 & 43.29 \\
\hline M3 & Loma Prieta, 1989 & APEEL 2 - Redwood City & A02043 & 0.274 & 53.65 \\
\hline M4 & Loma Prieta, 1989 & APEEL 2 - Redwood City & A02133 & 0.220 & 34.12 \\
\hline M5 & Loma Prieta, 1989 & $\begin{array}{c}\text { Foster City - Menhaden } \\
\text { Court }\end{array}$ & MEN270 & 0.110 & 21.98 \\
\hline M6 & Loma Prieta, 1989 & $\begin{array}{c}\text { Foster City - Menhaden } \\
\text { Court }\end{array}$ & MEN360 & 0.119 & 20.93 \\
\hline M7 & Loma Prieta, 1989 & Treasure Island & TRI000 & 0.100 & 15.59 \\
\hline M8 & Loma Prieta, 1989 & Treasure Island & TRI090 & 0.160 & 33.20 \\
\hline M9 & $\begin{array}{c}\text { Superstition Hills-02, } \\
1987\end{array}$ & $\begin{array}{c}\text { Imperial Valley Wildlife } \\
\text { Liquefaction Array }\end{array}$ & IVW090 & 0.179 & 31.67 \\
\hline M10 & $\begin{array}{c}\text { Superstition Hills-02, } \\
1987\end{array}$ & $\begin{array}{c}\text { Imperial Valley Wildlife } \\
\text { Liquefaction Array }\end{array}$ & IVW360 & 0.208 & 36.21 \\
\hline M11 & Northridge-01, 1994 & $\begin{array}{c}\text { Carson - Water St } \\
\text { Carson - Water St }\end{array}$ & WAT180 & 0.091 & 6.33 \\
\hline Northridge-01, 1994 & $\begin{array}{c}\text { WAT270 } \\
\text { M12 }\end{array}$ & 0.088 & 8.32 \\
\hline
\end{tabular}




\subsection{Results of structural seismic vulnerability assessment}

Seismic vulnerability assessment means calculate the probability of structural dynamic response exceeding a certain limit state $L S i$ with different ground motion intensity levels, i.e $P(L S i \mid I M=i m)$. Usually, we assume that DM for IM's condition distribution follows the lognormal cumulative distribution function. Then,

$P\left(L S_{i} \mid I M=i m\right)=P\left(D M>d m_{i} \mid I M=i m\right)=1-\Phi\left(\frac{\ln d m_{i}-\mu_{\ln D M \mid I M=i m}}{\sigma_{\ln D M \mid I M=i m}}\right)$

In formula (1), $\mu_{\ln D M \mid I M=i m}$ is the mean of $\ln (D M)$ and $\sigma_{\ln D M \mid I M=i m}$ is the standard deviation of $\ln (D M) . \Phi$ is the standard cumulative normal distribution function.

Based on the formula, we can obtain the seismic vulnerability curve with IM as horizontal axis, exceeding probability as vertical axis and the seismic vulnerability under specific ground motion intensity can be investigated. Based on the procedure mentioned above, the limit states of this station should be ensured firstly, which can refer to Liu et al. ${ }^{[5]}$, as illustrated in Table 4.
Then, the vulnerability curve can be obtained using formula (1) and nonlinear regression analysis of MATLAB, as shown in Figure 5.

In this study, we mainly investigate structural seismic vulnerability under the design seismic intensity and the rarely occurred seismic intensity at 7 degree $^{[8]}$. For design seismic intensity of 7 degree, PGA is equal to $0.1 \mathrm{~g}$ with the exceeding probability in 50 years of $10 \%$.

Table4. Thresholds at each limit state.

\begin{tabular}{|c|c|c|c|c|}
\hline $\begin{array}{c}\text { Limit } \\
\text { state } \\
(\mathrm{LS})\end{array}$ & $\begin{array}{c}\text { Operational } \\
\text { (OP) }\end{array}$ & $\begin{array}{c}\text { Slight } \\
\text { Damage } \\
(\mathrm{SD})\end{array}$ & $\begin{array}{c}\text { Life } \\
\text { Safety } \\
\text { (LY) }\end{array}$ & $\begin{array}{c}\text { Collapse } \\
\text { Prevention } \\
(\mathrm{CP})\end{array}$ \\
\hline$\theta_{\max }$ & 0.0011 & 0.0024 & 0.0065 & 0.0116 \\
\hline
\end{tabular}

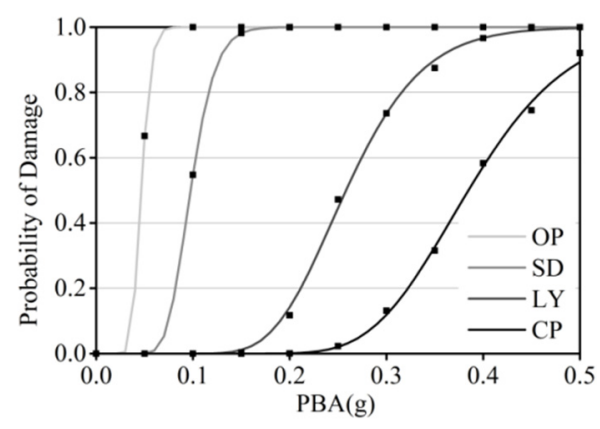

Figure 5. Seismic vulnerability curves

Table5. Exceeding probability at each limit state.

\begin{tabular}{|c|c|c|c|c|c|c|}
\hline & & & \multicolumn{4}{|c|}{ Limit state } \\
\cline { 4 - 6 } Seismic intensity & PGA(g) & PBA(g) & Operational & $\begin{array}{c}\text { Slight } \\
\text { Damage }\end{array}$ & $\begin{array}{c}\text { Life } \\
\text { Safety }\end{array}$ & $\begin{array}{c}\text { Collapse } \\
\text { Prevention }\end{array}$ \\
\hline $\begin{array}{c}\text { Design seismic intensity at } \\
7 \text { degree }\end{array}$ & 0.1 & 0.074 & $99.9 \%$ & $11 \%$ & $0 \%$ & $0 \%$ \\
\hline $\begin{array}{c}\text { Rarely occurred seismic } \\
\text { intensity at 7 degree }\end{array}$ & 0.22 & 0.160 & $100 \%$ & $99.2 \%$ & $2.2 \%$ & $0 \%$ \\
\hline
\end{tabular}

For rarely occurred seismic intensity of 7 degree, PGA is equal to $0.22 \mathrm{~g}$ with the exceeding probability in 50 years of $2 \%$. Then, we can calculate the corresponding mean value of PBA under specific seismic intensity and the exceeding probability of each limit state can be found through vulnerability curve in Figure 5, and the results are shown in Table 5.

It can be seen that the subway station structure may attain slight damage under design seismic intensity of 7 degree and the probability is $11 \%$. When it comes to the rarely occurred seismic intensity at 7 degree, the subway station may attain life safety limit state with the probability of $2.2 \%$. What's more, from the seismic vulnerability assessment result, the multi-storey subway station basically meets the design concept for underground structure that not damaged in medium earthquake and repairable in large earthquake.

\section{Conclusion}

In this study, seismic vulnerability assessment of multistorey subway station is conducted based on incremental dynamic analysis. The results are as follows.
(1) There's apparent discrepancy of IDA curves with different ground motion input.

(2) The multi-storey subway station structure investigated may attain slight damage under design seismic intensity of 7 degree and the probability is $11 \%$.

(3) When it comes to the rarely occurred seismic intensity at 7 degree, the subway station may attain life safety limit state with the probability of $2.2 \%$.

\section{Acknowledgements}

The research work in this paper was supported by LiaoNing Revitalization Talents Program, China (XLYC1902027), by Doctoral Scientific Research Foundation, China ( 2019 - BS- 193), by Science and Technology Project of MHRUD, China ( 2019 - K - 054 ), by Shenyang Science and Technology Project, China (RC200143) and Tianjin Science and Technology Project, China (18ZXGDGX00030). 


\section{References}

1. Iida H, Hiroto T, Yoshida N, et al. Damage to Daikai subway station[J]. Soils \& Foundations. 1996, 283300.

2. Huo H, Bobet A, Fernández G, et al. Load Transfer Mechanisms Between Underground Structure and Surrounding Ground: Evaluation of the Failure of the Daikai Station[J]. Journal of Geotechnical \& Geoenvironmental Engineering, 2005, 131(12): 1522-1533.

3. Cornell C A. Progress and Challenges in Seismic Performance Assessment[J]. Peer Center News. 2000, 20(2): 130-139.

4. Vamvatsikos D, Cornell C A. Incremental dynamic analysis $[\mathrm{J}]$. Earthquake Engineering \& Structural Dynamics. 2002, 31(3): 491-514.

5. Liu T, Chen Z, Yuan Y, et al. vulnerability Analysis of a Subway Station Structure by Incremental Dynamic Analysis[J]. Advances in Structural Engineering, 2017, 20(7): 1111-1124.

6. Zhong Z L, Shen Y Y, Zhao M, et al. Seismic vulnerability assessment of the Daikai subway station in layered soil. Soil Dynamics and Earthquake Engineering, 2020, 132: 106044.

7. ABAQUS, Users Manual V. 6.10-1. 2010. Dassault Systemes Simulia Corp., Providence, RI.

8. GB50011 (2010). Code for Seismic Design of Buildings, China Architecture \& Building Press, Beijing, China. 